Litinfinite Journal

ISSN: 2582-0400 [Online]

CODEN: LITIBR

Vol-1, Issue-2 (2 ${ }^{\text {nd }}$ December, 2019)

Page No: 1-4

DOI: 10.47365/litinfinite.1.2.2019.1-4

Section: Article

\title{
English Theatre in Colonial Calcutta: The Case of Mrs. Esther Leach
}

\author{
Dr. Samipendra Banerjee \\ Assistant Professor \\ Department of English - University of Gour Banga - West Bengal, India \\ Mail Id: samipendra@yahoo.com
}

\begin{abstract}
When it comes to scholarship on various aspects of Indian theatre, there is still a lot of work that remains to be done. One such area is the colonial theatre of old Calcutta during the nineteenth century. Modernity in the theatre arrived in India with the British and the English theatres of the time influenced the growth and development of Bengali and Indian theatre later. This brief paper examines the history of two playhouses of English theatre around the middle of the nineteenth century - the Chowringhee Theatre and the Sans Souci Theatre, and recounts how Mrs Esther Leach almost singlehandedly led the scene and established the Sans Souci theatre. This article glimpses at the performance culture of the time and wishes to rekindle interest in the theatres of a bygone era in order to better understand the history and politics of theatre.
\end{abstract}

Keywords: Theatre, Stage, Historiography, English actress, Colonial Calcutta

India has had a rich history of theatre and performance that goes back to the ancient periods. But in terms of research in Indian theatre and performance, a lot of work is yet to be done. Theatre and performance research in India is seen from three broad perspectivesperspectives on the Classical Sanskrit theatre, attitudes to traditional folk performances and the criticism of modern Indian theatre (including regional language theatres and Indian drama in English). Much of this work is textual and literary; criticism that evolves from reading and re-reading dramatic literature that has survived. However, for a more comprehensive historiography of our theatre and performance, we need to take into critical account broader historical/theatrical details. For example, there is still very little work on the traditions of acting and actor training, on the evolution and role of the director in theatre, to name a few. A major problem with such approaches to theatre scholarship is the apparent lack of historical evidence, accounts and materials. However, with new research tools and approaches to the fields of theatre historiography, unexplored terrains are opening up in theatre research.

This brief paper is premised on the above thoughts and would be an attempt to read into an area that is seldom discussed in critical discourses on theatre, namely the colonial theatre in old Calcutta. My recent interest in the old theatre and performance culture of Calcutta introduced me to the stories of colonial Calcutta's theatre and it has been a fascinating discovery in terms of performance history and gender equations. Three focal points can be 
CODEN: LITIBR

Vol-1, Issue-2 (2 ${ }^{\text {nd }}$ December, 2019)

Page No: 1-4

DOI: 10.47365/litinfinite.1.2.2019.1-4

Section: Article

located in this phase - the first being the establishment of the "Bengally Theatre" in 1795 by Gerasim Lebedeff, the Russian violinist; the second being the founding of "Hindu Theatre" in 1831 at the house of Prasanna Kumar Tagore and the third, of course, being the appearance of the Bengali public theatre in 1872. In fact, the entire nineteenth century Calcutta displays myriad theatre activity in various forms that tell a history of shifting centres and the rise and fall of celebrity actors and theatres. The entire span of this theatrical rendezvous is beyond the scope of this paper, but I would focus on an English actress of the nineteenth century, now almost forgotten, and her theatre.

The idea of modernity in Indian theatre is a colonial legacy. The British had brought modern theatre to India for their own entertainment, in the grand colonial cities of Calcutta and Bombay. The officers of the British East India Company did their best to replicate the English social life of London in Calcutta. Hence they had their magnificent 'retreats' or mansions in places like Dum Dum, tucked away from the 'busy' heart of the then Calcutta, and were proud of their "fashionable balls, their levees, their learned societies, their racemeetings, and their bonnet-shops" that "were every bit as good as anything that London could boast..." (Shaw 305) But they did not have a theatre like in England. Company officers hence tried their hand now and then in theatre, replicating in Calcutta what was happening in London's theatre. So, the first modern proscenium theatre was built in Calcutta in the late eighteenth century, quickly followed by others. But most of these amateur theatres were short- lived. These include the New Playhouse, the Wheeler and the Athaneum theatre, among others. However, two theatres continue to evoke the theatre scholar's imagination even today, namely - the Chowringhee Theatre and the Sans Souci Theatre. This paper concerns these theatres and the woman who led these theatres, Mrs. Esther Leach. Most scholars on the history of the Indian stage discuss the English theatres of Calcutta. In his monumental work, Sushil Kumar Mukherjee observes that "The Bengali theatre in Calcutta is a direct offshoot of the English theatre in the city..." (1). The historical significance of these theatres hence can hardly be undermined.

The Chowringhee theatre was established in 1813 and was distinct in its approach compared to other, earlier amateur British theatres. The plays that were chosen to be staged were the same as were common in eighteenth-century England; plays by Shakespeare, Congreve, Sheridan and Goldsmith. But Chowringhee theatre had brought in professional actors and actresses from London, actors who had performed in London's Drury Lane Theatre and Theatre Royal. Mrs. Esther Leach was first seen here in July 1826, as Lady Teazle in Sheridan's School for Scandal, a role that she had always cherished throughout her career in Calcutta. When Mrs. Leach had joined Chowringhee theatre, she was already reputed as a good actress, from her performances at the Dum Dum theatre. According to Dennis Shaw, "military officers stationed at Dum Dum, had brought back reports about the girl who acted with all the assurance and talent of a London leading lady" (305). It was arranged that Mrs. 
Litinfinite Journal

ISSN: 2582-0400 [Online]

CODEN: LITIBR

Vol-1, Issue-2 (2 ${ }^{\text {nd }}$ December, 2019)

Page No: 1-4

DOI: 10.47365/litinfinite.1.2.2019.1-4

Section: Article

Leach's husband got transferred to Fort William, enabling her to join the Chowringhee theatre, then the most important theatre in Calcutta, often nicknamed 'Calcutta's Drury' (305). Despite every effort, Chowringhee theatre suffered financial losses and like many such abrupt ends in theatre history, Chowringhee theatre caught fire and was destroyed in 1839. Before this, Mrs. Esther Leach had already announced her return to London following her husband's death and her declining health. The grandeur of her farewell benefit, as Shaw reports in detail, was an indication of her immense popularity among her audience. The Oriental Observer reported the next day that Mrs. Esther Leach

...took her farewell benefits to the fullest house ever seen at the Chowringhee Theatre. Quite apart from the attraction of the play, the simple and much lamented circumstance of her last appearance was ample incentive for such an assemblage. The house was literally crammedthere was, as the poet says, "no room for standing, miscalled standing room". Those, however few, that were not present on this interesting occasion have to regret the richest treat ever afforded to our histrionic world of India... In spite of the intense crowd the strictest silence was observed... when the beloved Mrs. Leach came forward to falter her valedictory address which, couched in the most apposite and affecting terms, was delivered with the in tensest pathos (Shaw 306).

Despite the grandeur of the farewell, her stay in England was short-lived, and Mrs. Esther Leach soon returned to Calcutta. The second phase of her career in Calcutta was more illustrious; she devoted herself to the construction of another theatre, the Sans Souci. She located a building at the crossing of Government place east and Waterloo Street (now Park Street/ Mother Teresa Avenue). The St Andrews Library operated from its first floor while the ground floor was more of a storehouse and lying vacant. Mrs. Leach chose this spot for her new theatre and the Sans Souci began operating from here with a seating capacity of about 400 in 1839. However, Mrs. Leach knew that she needed a larger playhouse and simultaneously worked for it. The construction of the new building was completed in 1840 . Mrs. Leach had appointed the renowned architect Mr. J. W Collins for the purpose and the Sans Souci theatre was relocated to its new venue, also on Park Street. The architecture of the Sans Souci theatre was remarkable. It was an enormous building resembling the Greek Parthenon with six Doric columns. The structure of the theatre measuring 200 feet in length and 50 feet breadth was built with a handsome portico in front. The stage occupied 28 feet in breadth, 50 feet depth, the space concealed from the audience above and below being appropriated to the green rooms etc." (puronokolkata)

Mrs. Leach, often referred to as "Mrs. Siddons of Bengal" was quite well known and her appeal for financial support for her new theatre was met with much enthusiasm. Lord Auckland, the then Governor-General, and Prince Dwarkanath Tagore, who had always been a leading figure among the Indians to encourage theatre in Calcutta, contributed a thousand rupees each. Apart from other leading Englishmen like Mr. Stocqeler, donations came from 

English theatre of Calcutta, Indians had been key contributors, and this is what set the Sans Souci apart. The theatre was inaugurated on 8 March 1841 with Sheridan Knowless's The Wife. Mrs. Leach impressed the audiences with her performance of Mariana. In its first two years, Sans Souci had become the talk of the town. Learning from her experience of the burning down of Chowringhee Theatre, Mrs. Leach had prohibited smoking in the Sans Souci Theatre, an unthinkable measure during that time. Two years later, in 1843, James Vining, a reputed actor at the Drury Lane and Covent Garden, joined Mrs. Leach at Sans Souci as actor cum stage-manager. On 2 November, two performances were scheduled: The Merchant of Venice, where Vining would play Shylock, Mrs. Deacle Portia, and Mrs. Leach would play Jessica; and The Handsome Husband. A fatal tragedy struck the theatre while the second play was going on. Mrs. Leach's gown caught fire from the oil lamps kept at the wings to illuminate the back stage and she was fatally burnt. The performance was called off. The Bengal Hurkaru reported the next day that Vining had reassured the audience "and announced that Mrs. Leach was in no great danger" probably from the reports of the three doctors who examined her then (Shaw 309). They were wrong. Mrs. Leach did not recover from her burns and passed away on 18 November. With her death the glory of the Sans Souci and in fact, the glory of the English theatre in Calcutta came to an end. Very soon, at the site of the Sans Souci, a school by the name of St. Xavier's would begin its long journey. However, by this time, in 1831, Prasanna Kumar Tagore's "Hindu Theatre" has appeared, changing the course of theatre in Calcutta.

Theatre is live performance art. Hence any research in nineteenth-century or older theatre, when the concept of documentation did not exist, is an arduous task and has to depend on the work of earlier historians and newspaper archives. This brief essay was not meant to offer a shadowy recollection of some of the English theatres of old Calcutta but to briefly introduce the theatre practices of British Calcutta and the single handed achievements of a woman actor, Mrs. Esther Leach, to the postcolonial and globalized reader of today. It is possible, with new methods in theatre research and historiography, to delve further into little known facts of our theatre history.

\section{Works cited}

i. Dasgupta, Hemendra Nath. The Indian Stage. Calcutta: Metropolitan Printing \& Publishing House, 1934.

ii. Mukherjee, Sushil Kumar. The Story of Calcutta Theatres. Calcutta: K.P. Bagchi and Co, 1982.

iii. Shaw, Denis. "Esther Leach: The Mrs. Siddons of Bengal". Educational Theatre Journal (10.4), 1958. pp. 304-310. JSTOR. https://www.jstor.org/stable/3203830. Web.

iv. অयाন্তিক. "Noisy." Puronokolkata, 14 July 2020, puronokolkata.com/tag/noisy/. 